\title{
IN VITRO TRYPANOCIDAL EVALUATION OF PINANE DERIVATIVES FROM ESSENTIAL OILS OF RIPE FRUITS FROM Schinus terebinthifolius RADDI (ANACARDIACEAE)
}

Patricia Sartorelli, Jefferson S. Santana, Rafael C. Guadagnin e João Henrique G. Lago*

Instituto de Ciências Ambientais, Químicas e Farmacêuticas, Universidade Federal de São Paulo, R. Prof. Artur Riedel, 275, 09972-279 Diadema - SP, Brasil

\section{Érika G. Pinto}

Departamento de Parasitologia, Instituto Adolfo Lutz, Av. Dr. Arnaldo, 355, 01246-000 São Paulo - SP / Instituto de Medicina Tropical de São Paulo, Universidade de São Paulo, Av. Dr. Enéas de Carvalho Aguiar, 470, 05403-000 São Paulo - SP, Brasil

André G. Tempone

Departamento de Parasitologia, Instituto Adolfo Lutz, Av. Dr. Arnaldo, 355, 01246-000 São Paulo - SP, Brasil

Hélio A. Stefani

Departamento de Farmácia, Faculdade de Ciências Farmacêuticas, Universidade de São Paulo, Av. Prof. Lineu Prestes, 580 , 05508-000 São Paulo - SP, Brasil

Marisi G. Soares

Instituto de Química, Universidade Federal de Alfenas, R. Gabriel Monteiro da Silva, 700, 37130-000 Alfenas - MG, Brasil

Adalberto M. da Silva

Departamento de Química, Universidade Federal de Viçosa, Av. Peter Henry Rolfs, s/n, 36570-000 Viçosa - MG, Brasil

Recebido em 8/7/11; aceito em 4/10/11; publicado na web 23/1/12

\begin{abstract}
Essential oils of ripe fruits from Schinus terebinthifolius (Anacardiaceae), obtained using a pilot extractor and a Clevenger apparatus were chemically characterized. Due the high amount of (-)- $\alpha$-pinene in both oils, this monoterpene was tested against the protozoan parasite Trypanosoma cruzi, showing a moderate potential $\left(\mathrm{IC}_{50} 63.56 \mu \mathrm{g} / \mathrm{mL}\right.$ ) when compared to benznidazole ( $\left.\mathrm{IC}_{50} 43.14 \mu \mathrm{g} / \mathrm{mL}\right)$. Otherwise, (-)- $\alpha$-pinene oxide did not showed anti-trypanosomal activity $\left(\mathrm{IC}_{50}>400 \mu \mathrm{g} / \mathrm{mL}\right)$ while (-)-pinane showed an $\mathrm{IC}_{50}$ of $56.50 \mu \mathrm{g} / \mathrm{mL}$. The obtained results indicated that the epoxydation of $\alpha$-pinene results to the loss of the anti-parasitic activity while its hydrogenation product, contributed slightly to the increased activity.
\end{abstract}

Keywords: Schinus terebinthifolius Raddi; Anacardiaceae; trypanocidal activity.

\section{INTRODUCTION}

Schinus terebinthifolius Raddi is a tree of medium size, monoecious, whose fruits have been used in cooking in France, where is known as poivre rose, a type of sweet pepper. This specie showed a spread occurrence in Brazilian territory, mainly in Atlantic Forrest regions. ${ }^{1,2}$ In folk medicine, this plant has been used as a remedy for ulcers, respiratory problems, wounds, rheumatism, gout, tumors, diarrhea, skin ailments, arthritis, ${ }^{3}$ and as an antiseptic, anti-inflammatory, balsamic, and haemostatic. ${ }^{4}$ Also, the decoction of flowers, leaves, and fruits are used for the treatment of tumors and lepra. ${ }^{5}$

Phytochemicaly, this specie is composed basically by fatty acids and terpenoids ${ }^{6-9}$ being two triterpenes characterized as specific inhibitors of phospholipase A2. ${ }^{10}$ Furthermore, chemical analysis of the bark showed the existence of anthraquinones, xanthones, and free steroids. ${ }^{11}$ Other compounds as methyl and ethyl galates and flavonoids with antiradicalar potential were also isolated from leaves extract. ${ }^{12}$ The essential oils from leaves, flowers, and fruits of $S$. terebinthifolius from different regions have been previously analyzed and several variations in their compositions were detected, ${ }^{13-17}$ but with predominance of monoterpenes and sesquiterpenes. A recent work describes the seasonal variation in the composition of volatiles from fruits of $S$. terebinthifolius, which showed allelopathic activity in vitro. ${ }^{18}$

As part of our on-going studies devoted to investigations on essential oils, ${ }^{19}$ this work describes the volatile composition of ripe

*e-mail: joao.lago@unifesp.br fruits from $S$. terebinthifolius, after extraction using two different methodologies. Considering that there is no report regarding the anti-parasitic activity of the essential oils of S. terebinthifolius, the main isolated component [(-)- $\alpha$-pinene] as well as its epoxydation [(-)- $\alpha$-pinene oxide] and hydrogenation [(-)-pinane] derivatives were tested in vitro against trypomastigote forms of Trypanosoma cruzi.

\section{EXPERIMENTAL}

\section{General procedures}

Silica gel 60 (Merck 230-400 and 63-200 mesh) was used for column chromatographic procedures. Optical rotations were measured in a digital polarimeter Perkin-Elmer model 343 . ${ }^{1} \mathrm{H}$ and ${ }^{13} \mathrm{C}$ NMR spectra were measured at 300 and $75 \mathrm{MHz}$, respectively, on a Bruker model DPX-300 spectrometer with sample dissolved in $\mathrm{CDCl}_{3}$ containing $1 \%$ of TMS (Aldrich). Unless stated otherwise, all other solvents were from Synth and Sigma. Pilot extractor was manufactured by Emontil Equipamentos e Montagens Industriais, Diadema, SP/Brazil while Clevenger type apparatus was obtained from MogiGlass Equipamentos e Materiais para Laboratório, Mogi das Cruzes, SP/Brazil.

\section{Plant material}

Ripe fruits from S. terebinthifolius were collected in Ouro Fino at Minas Gerais State, Brazil (349966-W/7536935-N) in March 30 ${ }^{\text {th }}$, 2008. The botanical identification of the plant was made by Profa. 
Dra. O. A. Fávero (UPM, São Paulo/SP) and the voucher specimen was compared with that under number SP272591, deposited in the Herbarium of Instituto de Botânica de São Paulo - SP, Brazil.

\section{Essential oils extraction procedures}

In the present work, two techniques for essential oils extraction were used. In the first method, $5.5 \mathrm{~kg}$ of fresh ripe fruits were extracted by steam distillation for $3 \mathrm{~h}$ using a pilot extractor with a capacity of $0.073 \mathrm{~m}^{3}$ at a temperature of $150{ }^{\circ} \mathrm{C}$ and pressure $2 \mathrm{~kg} / \mathrm{cm}^{2}$. After drying with anhydrous $\mathrm{Na}_{2} \mathrm{SO}_{4}$, were obtained $52.8 \mathrm{~g}$ of crude oil (yield $0.96 \%$ ). In the second method, $400 \mathrm{~g}$ of fresh ripe fruits were extracted by steam distillation in a Clevenger type apparatus for $4 \mathrm{~h}$, yielding $1.7601 \mathrm{~g}$ of crude essential oil (yield $0.44 \%$ ) after drying with anhydrous $\mathrm{Na}_{2} \mathrm{SO}_{4}$.

\section{Identification of oil components}

The oils were analyzed by GC and GC-MS using two different capillary columns (RtX-5 and RtX-wax). The identification of the individual compounds was performed by comparison of retention indexes (determined relatively to the retention times of a series of $n$-alkanes $)^{20}$ on both polar and non-polar columns and comparison of recorded mass spectra with those available in the system.

GC chromatograms were obtained on a Shimadzu GC-2010 gas chromatograph equipped with a FID-detector and an automatic injector (Shimadzu AOC-20i) using RtX-5 (5\% phenyl 95\% polydimethylsiloxane, Restek, USA - $30 \mathrm{~m}$ x $0.32 \mathrm{~mm}$ x $0.25 \mu \mathrm{m}$ film thickness) and RtX-wax (polyethylene glycol, Restek, USA - $30 \mathrm{~m} \mathrm{x}$ $0.32 \mathrm{~mm} \times 0.25 \mu \mathrm{m}$ film thickness), capillary columns. These analyses were done injecting $1.0 \mu \mathrm{L}$ of a solution at $1.0 \mathrm{mg} / \mathrm{mL}$ of volatile oil in $\mathrm{CH}_{2} \mathrm{Cl}_{2}$ in a split mode (1:30), employing helium as carrier gas ( $1 \mathrm{~mL} / \mathrm{min}$ ) under conditions: RtX-5 column - injector and detector temperatures as 250 and $280{ }^{\circ} \mathrm{C}$, respectively; oven programmed temperature from $60-280{ }^{\circ} \mathrm{C}$ at $3{ }^{\circ} \mathrm{C} / \mathrm{min}$, keeping $10 \mathrm{~min}$ at $280{ }^{\circ} \mathrm{C}$; RtX-wax column - injector and detector temperature as $250^{\circ} \mathrm{C}$; oven programmed temperature from $40^{\circ} \mathrm{C}$ for $5 \mathrm{~min}$ then $40-220^{\circ} \mathrm{C}$ at $3{ }^{\circ} \mathrm{C} /$ min, keeping $10 \mathrm{~min}$ at $220^{\circ} \mathrm{C}$. The percentage compositions of the oil samples were computed by internal normalization from the GC peak areas without using correction for response factors. Exclusively to $\alpha$-pinene analysis was used an Rt- $\beta$-DEXse $(\beta$-cyclodextrin, Restek, USA - $30 \mathrm{~m} \times 0.32 \mathrm{~mm} \times 0.25 \mu \mathrm{m}$ film thickness) capillary column, at the same conditions described to RtX-5 column. Mass spectra were obtained on a Shimadzu QP-5000 GC-MS-EI gas chromatograph/ mass spectrometer acquired in electron impact ion source operating at $70 \mathrm{eV}$, at the same conditions described above.

\section{Isolation of (-)- $\alpha$-pinene}

Part of crude oil obtained from Method 1 (6.0 g) was subjected to flash chromatography on Si-gel column $(60$ X $5 \mathrm{~cm})$ eluted with pentane $(400 \mathrm{~mL}), \mathrm{CH}_{2} \mathrm{Cl}_{2}(400 \mathrm{~mL})$ as well as with a gradient of $\mathrm{CH}_{2} \mathrm{Cl}_{2}-\mathrm{MeOH}$ 95:5 (300 mL) and 9:1 $(200 \mathrm{~mL})$ to afford fifty fractions (20 mL each) which were individually analyzed using gas chromatography. GC chromatograms of fractions 1-16 showed to be composed by complex mixtures of hydrocarbon derivatives. Thus, these fractions were pooled ( $2.6 \mathrm{~g}$ ) and purified by $\mathrm{SiO}_{2}$ gel coated with $\mathrm{AgNO}_{3}(10 \%)$ column chromatography $\left(40 \times 3 \mathrm{~cm}\right.$ ) eluted with pentane: $\mathrm{CH}_{2} \mathrm{Cl}_{2} 1: 1$ (400 mL) to afford $1533 \mathrm{mg}$ of pure $\alpha$-pinene ( $97 \%$ by GC), whose structure was identified by NMR and MS spectral analysis and comparison with literature data. ${ }^{21}$ Optical rotation measurement $[\alpha]_{D}{ }^{20}-46.3$ ( $\mathrm{MeOH}, c 2.9$ ), followed by chiral GC analysis, indicated that the major enantiomer (80\%) is the (-)-isomer (Figure 1). ${ }^{22}$

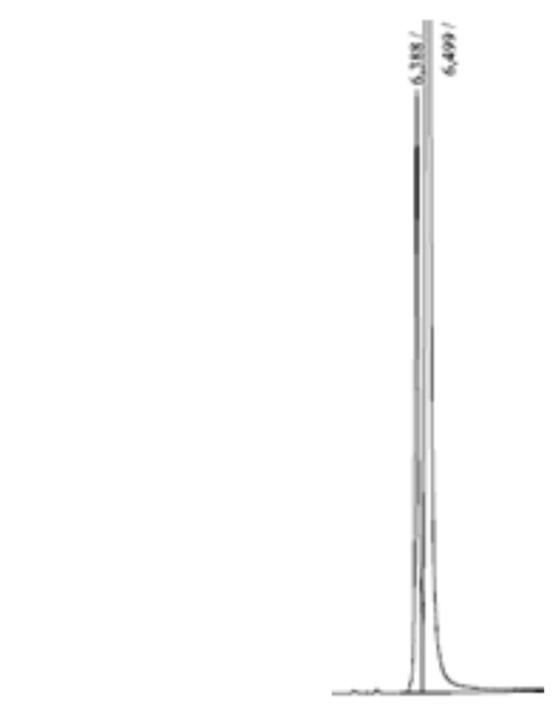

Figure 1. Analysis by chiral GC ( $\beta$-cyclodextrin) of $\alpha$-pinene isolated from ripe fruits of $S$. terebinthifolius

\section{Epoxydation of (-)- $\alpha$-pinene}

A solution of (-)- $\alpha$-pinene $(680 \mathrm{mg}, 5 \mathrm{mmol})$ in $\mathrm{CH}_{2} \mathrm{Cl}_{2}(5.0$ $\mathrm{mL})$ and $\mathrm{SiO}_{2}(0.5 \mathrm{~g}) / \mathrm{Al}_{2} \mathrm{O}_{3}(0.5 \mathrm{~g})$ was stirred with a solution of meta-chloroperbenzoic acid (1.0 g, $5.8 \mathrm{mmol})$ in $\mathrm{CH}_{2} \mathrm{Cl}_{2}(1 \mathrm{~mL})$ at $0{ }^{\circ} \mathrm{C}$ for $3 \mathrm{~h}$. Then, the product was filtered over a bed of Celite and extracted with saturated solution of $\mathrm{NaCl}(20 \mathrm{~mL})$ and $\mathrm{NaOH} 10 \%$ $(20 \mathrm{~mL})$. The organic solution was dried with anhydrous $\mathrm{MgSO}_{4}$ and the solvent was evaporated. The crude product was purified in $\mathrm{SiO}_{2}$ column chromatography eluted with hexane/EtOAc 98:2. This procedure afforded $870 \mathrm{mg}$ (yielding $88 \%$ ) of colorless oil which was characterized as (-)- $\alpha$-pinene oxide by NMR/EIMS analysis and comparison with literature data. ${ }^{23}$

(-)- $\alpha$-Pinene oxide. $[\alpha]_{\mathrm{D}}{ }^{20}-59.2\left(\mathrm{MeOH}\right.$, c 3.0). $\delta_{\mathrm{H}}(300 \mathrm{MHz}$, $\left.\mathrm{CDCl}_{3}\right): 0.90\left(\mathrm{~s}, \mathrm{CH}_{3}\right), 1.29\left(\mathrm{~s}, \mathrm{CH}_{3}\right), 1.30\left(\mathrm{~s}, \mathrm{CH}_{3}\right), 1.59$ (m), 1.72 (m), 1.91-1.98 (m), $3.01(\mathrm{~m}) . \delta_{\mathrm{C}}\left(75 \mathrm{MHz}, \mathrm{CDCl}_{3}\right): 60.1(\mathrm{C}-1), 56.7$ (C-2), 25.8 (C-3), 39.7 (C-4), 27.6 (C-5), 45.1 (C-6), 20.1 (C-7), 22.3 (C-8), 26.7 (C-9), 40.5 (C-10). EIMS (70 eV): $\mathrm{m} / \mathrm{z}$ (rel. int.): 152 (1), 137 (13), 123 (3), 119 (8), 109 (33), 95 (28), 83 (29), 67 (100), 55 (39), 43 (78), 41 (78).

\section{Hydrogenation of (-)- $\alpha$-pinene}

In a high-pressure reactor (stainless steel), was added (-)- $\alpha$-pinene (680 mg, $5 \mathrm{mmol}$ ) and Ni-Raney catalyst (10\%, $68 \mathrm{mg}$ ). After addition of $\mathrm{H}_{2}(8 \mathrm{~atm})$, the mixture was stirred for $2.5 \mathrm{~h}$ at $100{ }^{\circ} \mathrm{C}$. Then, the product was dissolved in hexane and the catalyst removed by filtration over a bed of Celite. After solvent evaporation, was obtained $682 \mathrm{mg}$ (yielding 99\%) of colorless oil which was characterized as (-)-pinane by NMR/EIMS analysis and comparison with literature data. ${ }^{24}$

(-)-Pinane. $[\alpha]_{\mathrm{D}}{ }^{20}-16.5\left(\mathrm{MeOH}, c\right.$ 2.3). $\delta_{\mathrm{H}}\left(300 \mathrm{MHz}, \mathrm{CDCl}_{3}\right)$ : $1.00\left(\mathrm{~d}, J=7.2 \mathrm{~Hz}, \mathrm{CH}_{3}\right), 1.02\left(\mathrm{~s}, \mathrm{CH}_{3}\right), 1.18\left(\mathrm{~s}, \mathrm{CH}_{3}\right), 1.20-1.34(\mathrm{~m})$, $1.74-2.32(\mathrm{~m}) . \delta_{\mathrm{C}}\left(75 \mathrm{MHz}, \mathrm{CDCl}_{3}\right): 48.2(\mathrm{C}-1), 36.0(\mathrm{C}-2), 28.3(\mathrm{C}-$ 3), 26.6 (C-4), 41.4 (C-5), 34.0 (C-6), 38.8 (C-7), 23.9 (C-8), 23.0 (C-9), 23.2 (C-10). EIMS (70 eV): $\mathrm{m} / z$ (rel. int.): 138 (1), 123 (16), 109 (6), 95 (69), 81 (42), 67 (60), 55 (89), 41 (100).

\section{Bioassays procedures}

$\mathrm{BALB} / \mathrm{c}$ mice and Golden hamsters were supplied by the animal breeding facility at the Adolfo Lutz Institute of São Paulo and 
maintained in sterilized cages under a controlled environment, receiving water and food ad libitum. Animal procedures were performed with the approval of the Research Ethics Commission, in agreement with the Guide for the Care and Use of Laboratory Animals from the National Academy of Sciences (http://www.nas.edu).

\section{Antitrypanosomal activity}

Cell culture-derived trypomastigotes from LLC-MK2 cells were counted in a Neubauer haemocytometer and seeded at $1 \times 10^{6}$ cells/ well in 96-well microplates. Pinane derivatives were incubated to the highest concentration of $150 \mu \mathrm{g} / \mathrm{mL}$ for $24 \mathrm{~h}$ at $37{ }^{\circ} \mathrm{C}$ in a $5 \%$ $\mathrm{CO}_{2}$ humidied incubator with benznidazole as the standard drug. The trypomastigotes viability was based on the cellular conversion of the soluble tetrazolium salt MTT into the insoluble formazan by mitochondrial enzymes. ${ }^{25}$ The formazan extraction was carried out with $10 \%$ (v/v) SDS for $18 \mathrm{~h}(100 \mu \mathrm{L} /$ well $)$ at $24^{\circ} \mathrm{C}$ in a spectrophotometer Multiskan MS (Uniscience) microplate reader.

\section{Statistical analysis}

The data obtained represent the mean and standard deviation of duplicate samples from two independent assays. The $\mathrm{IC}_{50}$ values were calculated using sigmoid dose-response curves in Graph Pad Prism 5.0 software, and the $95 \%$ confidence intervals are included in parentheses.

\section{RESULTS AND DISCUSSION}

The essential oils of ripe fruits from S. terebinthifolius were obtained using two different methods - hydrodistillation in a pilot extractor and using a Clevenger type apparatus. The identification of constituents was carried out using GC (polar and non-polar capillary columns) and GC-MS analysis associated to determination of their respective retention indexes. The crude oils showed to be composed basically by monoterpenes and sesquiterpenes, as could be seeing at Table 1, with predominance of $\mathrm{C}_{10}$ derivatives in the both samples.

The oil obtained using pilot extractor (Method 1) showed to be composed by nineteen derivatives, corresponding to $95.79 \%$ of the total identified volatiles. The main compounds were monoterpenes (-)- $\alpha$-pinene, $\beta$-pinene, myrcene, $\Delta^{3}$-carene, and limonene as well as the sesquiterpenes $\tau$-muurolol and $\alpha$-cadinol (concentration upper $5 \%$ ). Otherwise, the essential oil obtained using a Clevenger type apparatus (Method 2) showed to be composed by fifteen derivatives, corresponding to $99.10 \%$ of the crude oil. Comparatively to the oil obtained from pilot extractor, was detected quantitative but not qualitative differentiation in the hydrocarbon monoterpenes [(-)- $\alpha$-pinene, $\beta$-pinene, myrcene, $\Delta^{3}$-carene, and limonene as the main compounds], since the relative amount of these derivatives increased from approximately 55 to $77 \%$. Similarly, analyzing the proportion of oxygenated $\mathrm{C}_{10}$ derivatives in each extraction procedure, was possible detected an expressive quantitative differentiation in the relative amounts of terpinen-4-ol (Method 1-0.82\%; Method 2-3.42\%) and $\alpha$-terpineol (Method 1-2.65\%; Method 2-14.39\%).

The sesquiterpenes were abundant and showed a structurally diversification in each analyzed oils. However, the amount of hydrocarbon $\mathrm{C}_{15}$ derivatives was higher in the oil obtained using pilot extraction $(9.30 \%)$ in comparison with that obtained using Clevenger apparatus $(3.63 \%)$, in which $\delta$-cadinene was identified as main derivative in the both samples. Otherwise, the proportion of oxygenated sesquiterpenes showed to be more abundant in the oil obtained from Method $1(27.85 \%)$ in comparison to the oil from Method $2(0.31 \%)$,

Table 1. Chemical composition of the essential oils from ripe fruits of $S$. terebinthifolius using pilot extractor (method 1) and Clevenger apparatus (method 2)

\begin{tabular}{|c|c|c|c|c|c|c|}
\hline \multirow{2}{*}{$\begin{array}{c}\text { RI } \\
\text { RtX-5 }\end{array}$} & \multirow{2}{*}{$\begin{array}{c}\mathrm{RI} \\
\mathrm{RtX}-5^{*}\end{array}$} & \multirow{2}{*}{$\begin{array}{c}\text { RI } \\
\text { RtX-wax }\end{array}$} & \multirow{2}{*}{$\begin{array}{c}\text { RI } \\
\text { RtX-wax }^{a}\end{array}$} & \multirow{2}{*}{ Compounds } & \multicolumn{2}{|c|}{ Relative amount / \% } \\
\hline & & & & & Method 1 & Method 2 \\
\hline 939 & 939 & 1016 & 1036 & (-)- $\alpha$-pinene ${ }^{b}$ & 23.15 & 38.92 \\
\hline 980 & 980 & 1096 & 1120 & $\beta$-pinene & 5.97 & 0.36 \\
\hline 991 & 991 & 1164 & 1156 & myrcene & 8.29 & 10.05 \\
\hline 1011 & 1011 & 1142 & 1141 & $\Delta^{3}$-carene & 8.07 & 12.75 \\
\hline 1026 & 1026 & 1261 & 1250 & $p$-cymene & 1.45 & 2.90 \\
\hline 1031 & 1031 & 1188 & 1187 & limonene & 7.21 & 12.02 \\
\hline 1068 & 1068 & 1466 & - & cis-sabinene hydrate & 1.03 & 0.35 \\
\hline 1177 & 1177 & 1593 & 1601 & terpinen-4-ol & 0.82 & 3.42 \\
\hline 1189 & 1189 & 1693 & 1731 & $\alpha$-terpineol & 2.65 & 14.39 \\
\hline 1418 & 1418 & 1576 & 1617 & (E)-caryophyllene & 1.03 & 0.40 \\
\hline 1480 & 1480 & 1686 & 1712 & germacrene D & 0.59 & - \\
\hline 1497 & 1494 & 1710 & 1744 & bicyclogermacrene & 1.61 & 1.01 \\
\hline 1513 & 1513 & 1728 & 1792 & $\gamma$-cadinene & 1.11 & 0.79 \\
\hline 1524 & 1524 & 1741 & 1784 & $\delta$-cadinene & 4.95 & 1.43 \\
\hline 1549 & 1549 & 2037 & 2078 & elemol & 4.07 & - \\
\hline 1640 & 1640 & 2157 & 2136 & $\tau$-cadinol & 2.67 & - \\
\hline 1641 & 1641 & 2173 & - & $\tau$-muurolol & 5.12 & 0.16 \\
\hline 1653 & 1653 & 2217 & 2224 & $\alpha$-cadinol & 11.62 & 0.15 \\
\hline 1683 & 1683 & 2028 & 2022 & $\alpha$-bisabolol & 4.37 & - \\
\hline \multicolumn{5}{|c|}{ Hydrocarbon monoterpenes } & 55.17 & 77.35 \\
\hline \multicolumn{5}{|c|}{ Oxygenated monoterpenes } & 3.47 & 17.81 \\
\hline \multicolumn{5}{|c|}{ Hydrocarbon sesquiterpenes } & 9.30 & 3.63 \\
\hline \multicolumn{5}{|c|}{ Oxygenated sesquiterpenes } & 27.85 & 0.31 \\
\hline \multicolumn{5}{|c|}{ Total } & 95.79 & 99.10 \\
\hline
\end{tabular}

${ }^{a}$ literature data ${ }^{20} ;{ }^{b} 80 \%$ of (-)-isomer, as determined by chiral GC analysis. 
in which only the main compounds $\tau$-muurolol and $\alpha$-cadinol were detected in the both oils. The chemical compositions of essential oils from fruits of S. terebinthifolius from India and Brazil have previously been reported. The main compound found in these analysis was $\alpha$-pinene (15-60\%) but other derivatives such as germacrene D and $(E)$-caryophyllene were also described in high concentration, mainly in the oils from Brazilian plants. ${ }^{18}$ However, in the present study, these sesquiterpenes were found in low concentration with predominance of (-)- $\alpha$-pinene, indicating that the obtained oils could be used for commercial purposes. ${ }^{18}$

Finally, is important mentioned that the yields to each extraction procedure, determined on basis of fresh weight for fruits, were calculated as $0.96 \%$ (pilot extraction) and $0.44 \%$ (Clevenger apparatus). The obtained data indicated that despite of the higher yield obtained using Method 1, the relative amounts of hydrocarbon monoterpenes was lower (58.64\%) than those obtained using Method 2 (95.16\%). The opposite was observed to sesquiterpenes, being higher the amount of $\mathrm{C}_{15}$ derivatives when Method 1 was employed (37.15\% comparatively to $3.94 \%$ ). These results suggest a partial evaporation or oxidation/degradation of more volatile constituents when different parameters such as pressure and temperature have been used to essential oil extraction.

Based in some evidences that extracts ${ }^{26}$ and essential oils ${ }^{27}$ from Schinus species showed several biological potential, our results demonstrated that the monoterpene (-)- $\alpha$-pinene, the main derivative identified in the crude oils, showed moderate anti-trypanosomal activity, with an $\mathrm{IC}_{50}$ of $63.56 \mu \mathrm{g} / \mathrm{mL}$ (Figure 2). Through the mitochondrial viability test (MTT), it was also possible to confirm the trypanocidal activity of this compound, which killed $100 \%$ of trypomastigotes at the highest tested concentration after $24 \mathrm{~h}$ incubation. Benznidazole was used as standard drug and resulted in an $\mathrm{IC}_{50}$ of $43.14 \mu \mathrm{g} / \mathrm{mL}$. Additionally, aiming to establish preliminary structure/ activity relationships, (-)- $\alpha$-pinene was subjected to epoxydation and hydrogenation procedures affording, respectively, (-)- $\alpha$-pinene oxide and (-)-pinane. The epoxyde derivative was completely devoid of activity against tested parasites at the highest tested concentration $(400 \mu \mathrm{g} / \mathrm{mL})$, while the anti-trypanosomal activity of the hydrogenated derivative [(-)-pinane] was determined as $56.50 \mu \mathrm{g} / \mathrm{mL}$, higher than the original (-)- $\alpha$-pinene. These results indicated that the presence on oxygen atom as epoxide derivative in the pinane skeleton significantly reduces its trypanocidal activity while the hydrogenation of double bound of (-)- $\alpha$-pinene increased its toxicity to trypomastigote forms of $T$. cruzi.

In conclusion, the chemical analysis carried out with essential oils from ripe fruits of $S$. terebinthifolius indicated that its major

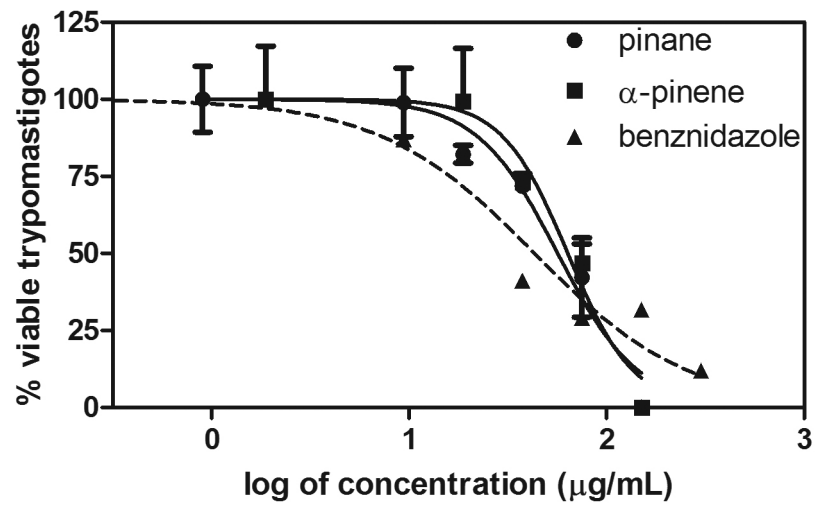

Figure 2. Determination of 50\% inhibitory concentration of compounds against T. cruzi trypomastigotes. The parasite viability was determined by the mitochondrial oxidation of MTT at $550 \mathrm{~nm}$. Benznidazole (dashed line) was used as standard drug component (-)- $\alpha$-pinene might be responsible for the observed trypanocidal effect to the crude oils. Considering that the flowers, leaves, and fruits of S. terebinthifolius are used in traditional medicine for the treatment of several tropical diseases, ${ }^{28}$ our results are in good agreement with the medicinal use of this species. However, additional non-clinical trials of these oils and isolated (-)- $\alpha$-pinene have to be performed aiming the use for medicinal purposes.

\section{ACKOWLEDGMENTS}

The authors thank FAPESP and CNPq for financial support for the development of this work. The authors are grateful to Atina Natural Assets, Pouso Alegre/MG to extraction of volatile oils in the pilot extractor and to Prof. O. A. Fávero (UPM) for the identification of plant material.

\section{REFERENCES}

1. Pio-Corrêa, M.; Dicionário de Plantas Úteis do Brasil e das Exóticas Cultivadas, Ministério da Agricultura/IBDF, Imprensa Nacional: Rio de Janeiro, 1984.

2. Lorenzi, H.; Árvores Brasileiras: manual de identificação e cultivo de plantas arbóreas nativas do Brasil, Editora Plantarum: São Paulo, 1992.

3. Morton, J. F.; Economic Bot. 1978, 32, 353.

4. Medeiros, K. C. P.; Monteiro, J. C.; Diniz, M. F. F. M.; Medeiros, I. A.; Silva, B. A.; Piuvezam, M. R.; Braz. J. Pharmacog. 2007, 17, 23.

5. Schmourlo, G.; Mendonça-Filho, R. R.; Alviano, C. S.; Costa, S. S.; J. Ethnopharmacol. 2005, 96, 563.

6. Moneam, N. M. A.; Ghoneim, T.; J. Chromatogr., A 1986, 361, 391.

7. Lloyd, H. A.; Jaouni, T. M.; Evans, S. L.; Morton, J. F.; Phytochemistry 1977, 16, 1301

8. Campello, J. P.; Marsaioli, A. J.; Phytochemistry 1975, 14, 2300.

9. Campello, J. P.; Marsaioli, A. J.; Phytochemistry 1974, 13, 659.

10. Jain, M. K.; Yu, B. Z.; Rogers, J. M.; Smith, A. E.; Boger, E. T. A.; Ostrander, R. L.; Rheingold, A. L.; Phytochemistry 1995, 39, 537

11. Lima, M. R. F.; Luna, J. S.; Santos, A. F.; Andrade, M. C. C.; Sant'ana, A. E. G.; Genet, J. P.; Marquez, B.; Neuville, L.; Moreau, N.; J. Ethnopharmacol. 2006, 105, 137.

12. Ceruks, M.; Romoff, P.; Fávero, O. A.; Lago, J. H. G.; Quim. Nova 2007, $30,597$.

13. Ibrahim, M. T.; Fobbe, R.; Nolte, J.; Bull. Fac. Pharm. 2004, 42, 289.

14. Singh, A. K.; Gupta, K. C.; Brophy, J. J.; J. Essent. Oil Res. 1998, 10, 697.

15. Jamal, Y.; Agusta, A.; Maj. Farm. Indo. 2001, 12, 135.

16. Chowdhury, A. R.; Tripathi, S.; Ind. Perfum. 2001, 45, 257.

17. Malik, M. S.; Mahmud, S.; Sattar, A.; Pak. Sci. Int. (Lahore) 1994, 6 , 351.

18. Barbosa, L. C. A.; Demuner, A. J.; Clemente, A. D.; Paula, V. F.; Ismail, F. M. D.; Quim. Nova 2007, 30, 1959.

19. Lago, J. H. G.; Carvalho, L. A. C.; da Silva, F. S.; Toyama, D. D.; Favero, O. A.; Romoff, P.; J. Braz. Chem. Soc. 2010, 21, 1760; Soares, M. G.; da Silva, M. F. D. G.; Fernandes, J. B.; Lago, J. H. G.; Quim. Nova 2010, 33, 1141; Lago, J. H. G.; Romoff, P.; Favero, O. A.; Soares, M. G.; Baraldi, P. T.; Correa, A. G.; Souza, F. O.; Quim. Nova 2008, 31, 727.

20. Adams, R. P.; Identification of essential oil components by gas chromatography/quadrupole mass spectrometry, Academic Press: San Diego; 1995; Davies, N. W.; J. Chromatogr., A 1990, 503, 1.

21. Kubeczka, K. H.; Formácek, V.; Essential oils analysis by capillary gas chromatography and carbon-13 NMR spectroscopy, $2^{\text {nd }}$ ed., Wiley: New York, 2002.

22. Castro, J. M.; Linares-Palomino, P. J.; Salido, S.; Altarejos, J.; Nogueras, M.; Sanchez, A.; Tetrahedron 2005, 61, 11192. 
23. Saladino, R.; Neri, V.; Pelliccia, A. R.; Mincione, E.; Tetrahedron 2003, $59,7403$.

24. Bazhenov, Y. P.; Kasyanova, L. Z.; Bokin, A. I.; Kutepov, B. I.; Khazipova, A. N.; Travkin, E. A.; Shchadneva, N. A.; Khusnutdinov, R. I.; Dzhemilev, U. M.; Russ. J. Appl. Chem. 2003, 76, 232.

25. Corrêa, D. S.; Tempone, A. G.; Reimão, J. Q.; Taniwaki, N. M.; Romoff, P.; Fávero, O. A.; Sartorelli, P.; Mecchi, M. C.; Lago, J. H. G.; Parasitol. Res. 2011, 109, 231; Reimão, J. Q.; Scotti, M. T., Tempone, A. G.; Bioorg. Med. Chem. 2010, 15, 8044.
26. Ruffa, M. J.; Ferraro, G.; Wagner, M. L.; Calcagno, M. L.; Campos, R. H.; Cavallaro, L.; J. Ethnopharmacol. 2002, 79, 335.

27. Díaz, C.; Quesada, S.; Brenes, O.; Aguilar, G.; Cicció, J. F.; Nat. Prod. Res. 2008, 22, 1521.

28. Mesquita, M. L.; de Paula, J. E.; Pessoa, C.; de Moraes, M. O.; CostaLotufo, L. V.; Grougnet, R.; Michel, S.; Tillequin, F.; Espindola, L. S.; J. Ethnopharmacol. 2009, 123, 439; Schmourlo, G.; Mendonça-Filho, R. R.; Alviano, C. S.; Costa, S. S.; J. Ethnopharmacol. 2005, 96, 563. 